\title{
Levinas and the Possibility of Dialogue with 'Strangers'
}

AB (Benda) Hofmeyr

Department of Philosophy, University of Pretoria

\section{Short bio:}

Benda Hofmeyr is currently affiliated to the Department of Philosophy, University of Pretoria, South Africa. She lived and worked in the Netherlands while completing her doctoral studies and postdoctoral research. She still maintains strong collaborative ties with the Radboud University Nijmegen where she obtained her doctoral degree in Philosophy on the work of Foucault and Levinas. Her research interests fall within the broad ambit of contemporary Continental philosophy with an enduring fascination for the inextricable entanglement of the ethical and the political. For more information: benda.hofmeyr@up.ac.za and/or www.bendahofmeyr.com

\section{Keywords:}

Levinas; ethical metaphysics; Eurocentrism; racism; the Other; dialogue; the relation between ethics and politics; alterity; ethical responsibility

\begin{abstract}
This programmatic essay explores some of the challenges that a seemingly quintessential European or Continental philosopher such as Levinas faces when his thought on alterity and on the responsibility we bear towards the Other, is brought face-to-face with other (non-Western) ways of thinking alterity and especially difference(s). Given the fact that Levinas's entire oeuvre is dedicated to exposing the violent reductionism at work in Western philosophy, a colonizing tradition par excellence that establishes its self-certainty by way of usurping anything and everything that is other-than-itself, such an encounter seems critical. Yet, Levinas and his thinking seem to be burdened with a number of inherent biases that severely compromise any
\end{abstract}


possibility of dialogue. These include the fact that Levinas's notion of an abstract Alterity does not account for differences; his undeniable Eurocentric bias and racist prejudice; and finally, the irreconcilability of ethics and politics in this thinking. This essay attempts to address these indictments head on an attempt to prepare the ground for future research that will endeavour to stage an actual encounter between Levinas and his non-Western counterparts.

\section{Introducing the Problematics}

To what extent is a productive encounter between Levinas's thought and non-Western and postcolonial ethical frameworks and conceptions of difference and alterity possible? This programmatic essay will certainly not be able to answer this question - not even in part. It does, however, endeavour to lay the groundwork upon which we might start to explore such an encounter by first critically assessing some of the stumbling blocks in the way of dialogue. Upon closer inspection, Levinas and his thought are beset by prejudices that cast a disparaging shadow over his well-known exposure of the violence at the very heart of Western philosophy - the reductive tendency to the Self to reduce, subject or 'colonize' all forms of alterity that cross its path. Within the canon of contemporary Western philosophy, his has been one of the most prominent voices - alongside those of Rosenzweig, Buber, Ricœur, Derrida, Honneth and many others - to place the inherent responsibility we bear towards others centre stage. It could be argued that Levinas's ethical metaphysics spearheaded a decisive re-construal of the decentred subject of the second half of the 20th $\mathrm{C}$ in terms of its fundamental relatedness to the Other. This Other is not merely the one who appeals to me in the face of the beggar, the orphan or the widow, as the Levinas of Totality and Infinity (1961) famously contends. In his second magnum opus, Otherwise Than Being and Beyond Essence (1974), Levinas more radically insists that this Other is an alterity lodged within the self. As we shall see, Levinas's conception of alterity is of a completely different order than the alterity of Strangers - i.e. those others of non-Western 
cultures that belong to the mundane historical world, revealed in being horizontally (horizontalement). Levinas's alterity is the alterity of transcendence - an epiphany of what Levinas calls "sense" that breaks through the horizontality of cultural meaning. ${ }^{1}$ When considering the possibility of a critical encounter between Levinas with his conceptualization of the Other as an alterity of transcendence, and non-Western conceptions of the other - that would be the alterity of Strangers from a Levinasian vantage point - , one faces a number of challenges:

First and foremost, Levinas has been guilty of a number of explicitly racist remarks. For example, in "The Russo-Chinese Debate and the Dialectic" ${ }^{2}$ on the Sino-Soviet tension, an article published in 1960 in Esprit, Levinas writes:

'The exclusive community with the Asiatic world, itself a stranger to European history to which Russia, in spite of all its strategic and tactical denials, has belonged for almost a thousand years, would this not be disturbing even to a society without classes? ... In abandoning the West, does not Russia fear to drown itself in an Asiatic civilization which, it too, is likely to carry on existing behind the concrete appearance of dialectical resolution?"3

According to Caygill, "[t] he evocation of a national and then a European identity that must be protected against a culture that is a stranger to its history, the figuration of contact with the other in terms of drowning, would seem to invert all of the theses of Levinas's thought". ${ }^{4}$ Levinas continues by describing the Chinese as "the yellow peril", which he qualifies as not being "racial" but rather "spiritual". "It does not involve inferior values", he contends, "it involves a radical strangeness, a stranger to the weight of its past, from where there does not filter any familiar voice of inflection, a lunar or Martian past" (my emphasis). ${ }^{5}$ Levinas's disclaimer appears quite vacuous since it is nearly impossible to conceive of any circumstances in which such a designation would be considered anything other than blatantly racist, let alone this particular context in which Levinas "consigns a phantasm of Asia to the moon or another planet, thus figuratively stripping Asians of their humanity", as Caygill observes. ${ }^{6}$ Levinas's insistence upon the "radical 
strangeness" of the Chinese resonates with his suggestion elsewhere that the Asiatic is a stranger to Abraham. Isaac and Jaboc. ${ }^{7}$ In this essay, 'Jewish Thought Today', Levinas refers to '[t]he arrival on the historical scene of those underdeveloped Afro-Asiatic masses who are strangers to the Sacred History that forms the heart of the Judaic-Christian world" (my emphasis). ${ }^{8}$ Levinas seems to suggest that the long history of the Asiatic tradition lacks genuine significance, because it is devoid of the dimension of transcendence. He further worries - a concern that smacks of xenophobia - that the demands of the "underdeveloped Afro-Asiatic masses" - the strangers might endanger the authenticity of the State of Israel and marginalize Jews and Christians. ${ }^{9}$

Levinas's racist proclivities surfaced again in a 1991 interview in which he said:

'I often say, though it's a dangerous thing to say publicly, that humanity consists of the Bible and the Greeks. All the rest can be translated: all the rest - all the exotic - is dance'. ${ }^{10}$

What, then, about all those outside the influence of the Bible and the Greeks? What about those people who accept submission to the law, but not the Judaic-Christian law, for does not Islam, as Critchley rightly points out, mean 'submission'? ${ }^{11}$ It could arguably be interpreted to mean that the ethical responsiveness that Levinas theorizes would, on the one hand, be a responsiveness to others, but not to others that are 'too strange', and, on the other hand, only be sanctioned by the Judaic-Christian law. Only those who subject themselves to this particular law, count among those able to realize their full human potential as ethical beings.

Apart from these unpalatable racist remarks, which were imprudently uttered in interviews and in the odd commentary on political affairs rather than in his systematic philosophical writings, Levinas's work is undeniably Eurocentric. The Eurocentric bias persists even as his thought proposes to critique the totality underpinning the history of Western philosophy with the infinity of the ethical encounter. Levinas's Eurocentrism is premised on a very narrow conception of Europe: for him it is clear, "Europe is the Bible and the Greeks"12, which, as we shall see, wants 
to foreground the generosity of the Hebraic tradition as well as the wisdom and rationality rooted in a Hellenic lineage, but excludes the constitutive violence of Europe the 'empire'.

Another aspect of Levinas's thought that poses a significant challenge to the possibility of dialogue with non-Western conceptions of identity and difference is the fact that his conceptualization of alterity allows no distinction from, comparison to, or derivation from identity. Radical difference for Levinas is in a definitive way abstract and unphenomenolizable. It cannot be conceived or reduced to an empirical appearance and therefore cannot be compared to or distinguished from other others. As we will see, Levinas insists that alterity does not follow from differences; differences issue from alterity.

Ethical frameworks of identity and difference, by their very nature, are mostly conceived to function within the concrete socio-political world of decision-making and action. Levinas's conceptualization of the ethical appeal, and the necessity of justice also for the self in the political world, signal two opposing forces bearing on the self. Moreover, many commentators agree that his political thought has seriously weakened the appeal and force of his ethical metaphysics. ${ }^{13}$ The relation between ethics and politics remains a thorn in the flesh of both sympathizers and critics of Levinas for there is the seemingly insurmountable gap between ethics - a relation limited to the singular self and the Other person - and politics, the realm where the countless appeals of other Others impinge upon the face-to-face relation. In light of these challenges, one might wonder what scope there is - if any - for a productive interchange between ethical metaphysics and other more 'exotic' conceptualizations such postcolonial celebrations of differences (think, for example, of Negritude, Black consciousness, the fact of blackness, and so on).

Many ethical discourses and the entire postcolonial 'oeuvre' as such are expressly ethico-political with a decisive emphasis on the politics of difference and oppression. Levinas's philosophy, on the other hand, is to a great extent a-political. To be fair, from a certain meta-perspective, Levinas's ethical metaphysics operates to destabilize politics, and to animate and inspire it in a 
radically new way. It nevertheless can be considered a-political or very narrowly political at best, in the sense that he showed very little interest in world affairs, apart from his preoccupation with the Holocaust and the fate of the Jewish people. Even his discussion of the Sino-Soviet tension is at bottom driven by a particular political agenda, which Caygill describes as "particular radical nationalism", namely "Arab nationalism and above all the Nasserite regime in Egypt" characterized by a "hostility towards the existence of the State of Israel"14. The fissure between ethics and politics persists even though Levinas insists that ethics necessarily entails politics: the ethical encounter between the self and the Other always also implicates other others. The singularizing asymmetric responsibility that cannot be evaded or delegated, which issues from the Other's appeal (that is, ethics, in Levinas's sense) reintroduces thought, knowledge, and judgment (that is, ontology) - having to compare the incomparable appeals of countless Others laying claim to the limited resources of the self.

In the following sections, I will flesh out this bare-bones sketch by focusing on three challenges that, to my mind, need to be addressed if a productive encounter between Levinas and the 'radical strangeness' of non-Western ethical frameworks is to be possible. The critical question, which I fear I might not be able to answer definitively here, bears on the critical and liberatory power of Levinas's thought as opposed to its possible complicity: can Levinas's ethical metaphysics contribute to 'decolonizing the mind' or does his racism, the eurocentric and apolitical nature of his thought, in conjunction with his insistence upon an abstract Alterity render it an instance of the structural violence responsible for the marginalization of difference(s) and/or otherness? The aspect of Levinas's thought foregrounded in the preceding section casts a disheartening shadow over the prospect of a truly productive encounter between Levinas and possible non-Western interlocutors. To level the playing field, the next section will briefly re-visit the better known Levinas-as-ethical-thinker by surveying his notions of the self, the Other understood as radical alterity, ethical subjectivity and the nature and (im)possibility of ethical agency. Within this context, Levinas's conceptualization of racism as the most extreme form of 
moral evil will prove to be instructive. As we will see, Levinas conceives of moral evil as the reduction of the absolute Otherness of the Other person to the non-human otherness of a totality, of a species in which Otherness loses its singularity and is simply treated as one more of a kind.

\section{Self and Other: Immanence vs. Transcendence?}

Levinsas conceives of the being of the self in terms of the Spinozian conatus essendi, that is, the persistent concern with its own existence. ${ }^{15}$ The 'natural' or spontaneous being of the I is the striving (conatus) to persevere in being as self-interest. Put differently, the self is ontologically driven to maintain itself in existence and to self-actualize. It therefore approaches the Other person from an 'interested' position, that is, it tries to integrate the Other into its project of existing as function, means, or meaning, and therefore cannot but be a violating, reductive and totalizing force. Levinas's project could be understood as a sustained attempt to come to grips with the conditions of possibility of ethical action. He defines ethical action as placing the needs of the other person before that of the self. In light of our conatus, ethical action is an improbable occurrence, since we are naturally inclined or ontologically programmed to be concerned with ourselves first and foremost. By our very being, we are preoccupied with our own continued existence - the drive to sustain ourselves or to care for the self. By virtue of this inherent selfinterestedness, the self tends to assume a instrumentalist approach to all that is other, wanting to consume all forms of alterity it comes into contact with for the sake of sustenance and survival. Levinas's Other, on the other hand, is the other person that confronts the self as absolute alterity. As such, the other person - who, for Levinas, is the Other par excellence (hence the capitalization) - is the only form of otherness capable of resisting the self's violence. The epiphany of the Other as "face" refuses reduction to its plastic form ${ }^{16}$, for no representation can contain Infinity. In other words, Levinas's Other cannot be recognized by way of complexion or ethnicity, cannot be categorized, for example, as 'Field Negro' or 'House Negro'17, and makes no 
distinction between 'conquerors' and 'immigrants', 'natives' and 'settlers'. Levinas's Other is absolute in his or her alterity, defying all representation and any reduction to recognizable traits. In fact, Levinas insists that this difference is absolute in the sense that it is different by virtue of itself and not by comparison to others. This difference precedes all differences. Alterity, he insists, does not follow from differences; alterity is fundamental and in no way tied to incidental differences in complexion, ethnic identity, sexual orientation, gender, or whatever.

When I encounter this Other, he or she shows him- or herself as 'face' - a revelation that cannot be encapsulated in physical, observable features. The face furthermore affects me like a force, a force which I cannot not feel. In this sense, the face poses an ethical (as opposed to a concrete) resistance to my reductive being. It is not so easy to do violence to someone - as opposed to something. The face challenges my self-interested effort of existing, which reduces alterity to sameness, but does not make it impossible. It is not so easy to do violence to someone, but it is not impossible. Not only is it not impossible, it is a banal fact. After all, we live in a world rampant with hatred, discrimination, disrespect, and worst of all, indifference. Despite the pervasiveness of Other-reductive violence, Levinas insists that the authority of the face, what he hyperbolically describes as the commandment against murder, is maintained in bad conscience over evil committed. ${ }^{18}$ I can commit violence, but in the act I recognize it as violence. Hereby the ethical is theorized as a 'possibility' albeit a possibility against all odds, as opposed to a 'compulsion' or 'inevitability' (and certainly not as prescriptive normative moral framework): the face does not force compliance, but only appeals. Ethical action is made possible by a moment of 'radical passivity' that enables a momentary suspension of one's conatus. This arrest of selfinterest enables dis-interest, i.e. an action for the other with no regard for self - a selfless act.

According to Levinas, the Other person has this power over me, because the Other is vested with the trace of Infinite. The Infinity of the Other derives from transcendence, which cannot appear other than as incarnated immanence, the other person. It is the Cartesian idea of Infinity placed in the I by the Infinite - that foreign kernel at the heart of the self that paradoxically 
constitutes the self as an identity in dia-stasis. As such, the self is always troubled by the otherwithin-the self, and is fundamentally incapable of ever fully coinciding with itself. The Other-inthe Self is in actual fact an enigmatic anachronism, since it would be more accurate to describe this being-troubled as a 'will always already have been troubled'. A (future) encounter with the Other is needed to bring to the present a constitutive inscription by alterity that predates the self. In other words, the placing of the idea of Infinity is an-archic, it is always-already there, an inherent potential that realizes the humanity in the human. What makes us truly human is precisely our ability to suppress our ontological concern for oneself. This 'ability' is more precisely a predisposition or potential, which becomes actualized by way of an encounter with a vulnerable Other that 'activates' the uniquely human capacity for ethical action. Levinas describes this 'trigger' as an affectation. The ability to transcend or rise above our ontological self-interest is triggered by a feeling. Transcendence is the double movement of trans-ascendence and trans-descendence: in the latter case, it is a movement downwards and inwards, reconfiguring the very ontological structure of the I: a denucleation whereby the ego is hollowed out, stripped of its egotism. In the process, the fundamental self-interestedness of the I is turned outward to face its responsibility towards the other person, trans-ascending its very conatus. ${ }^{19}$

The self and the Other should nevertheless not be conceived of as two poles of a binary opposition. Levinas conceives of this relationship in terms of 'and' rather than 'or'. In fact, the 'and' of Totality and Infinity (1961) became a definitive (Derridean) 'both/and' in Otherwise Than Being and Beyond Essence (1974), in which Levinas insists that the Other is in the self. ${ }^{20}$ The encounter with the other person triggers an inherent, fundamental alterity that 'always-already' disturbs self-interestedness. The possibility of ethical action is thus the paradoxical simultaneity of the necessary persistence in being, and the an-archic, pre-original, pre-reflective (alwaysalready) possibility of going against the grain of one's ontological blueprint, that is, the possibility to be otherwise-than-being and to go beyond the logic of one's conatus. Levinas already introduces and insists upon this simultaneity in Totality and Infinity, but it only becomes fully 
articulated in Otherwise Than Being. In the latter work the emphasis is wholly on the traumatization of the ethical encounter, and the preceding economics of existence in the world, discussed at length in Totality and Infinity, is even disavowed. In Totality and Infinity, the separation of the I remains a necessary condition for the possibility of the ethical relation. Here, in his first magnum opus, the emphasis is on establishing the difference between need and desire. The need of an indigent $\mathrm{I}$ and its instrumentalist relationship to provisional otherness in the world that it requires to sustain itself, is distinguished from desire, which does not belong to the economy of need and satisfaction. As an insatiable going-towards the Other person, desire signals a relationship of disinterest, where the $\mathrm{I}$ is not in need and fully independent. It can therefore engage the Other without self-interest. Once this distinction has been established, Levinas shifts his concern in the later Otherness Than Being to the impact of the fully separated I's encounter with absolute alterity where the trope of traumatization is central. The encounter with the Other is a traumatizing hollowing out of the self's egoist core. Stripped of self-concern, selfless or disinterested concern for the Other becomes possible.

The alterity at the very heart of the self, which enables being 'otherwise than Being', therefore comes to the fore as essentially belonging to the dynamic of conatus: always at odds with itself needing to continue in self-persistence, but troubled by the possibility that this effort to exist is at the expense of another's. This explains Levinas's postulation of the possibility of a "good will" made possible by "bad conscience".

\section{Racism: Alterity vs. Difference}

Racism, for Levinas, is the most extreme form of moral evil understood as the reduction of the absolute otherness of the Other (the face), to the non-human otherness of a totality, of a species in which Otherness loses its singularity and is simply treated as one more of a kind. ${ }^{21}$ Reduction to qualities totalizes rather than singularizes. It does not recognize my uniqueness but reduces my singularity as person - who's also another person's Other - to empirical qualities, such as 
complexion, gender, race, etc. A reductive totalizing gaze will render me nothing but white (on a predominantly black continent), female (to my (still) predominantly male interlocutors), and of settler-descent, as if these qualities are all that I am.

Levinas insists that diversity - differences that result from different qualities - is antecedent to Otherness/absolute alterity. ${ }^{22} \mathrm{I}$ am other fundamentally and preceding any observable differences much like identical twins are alike in nothing more than appearance. They might be borne from the same gene pool and socialized in an identical setting, but they nevertheless remain irreducible singularized by a fundamental alterity that cannot be overcome - neither by nature nor by nurture. To recognize the Other as a face "without any cultural adornment" 23 is to refuse to subject persons to any such reduction which would rob them of their unique irreplaceability, and make them into another one of a kind/species.

If the self is driven by self-interest and our encounters with others are predominantly dictated by a means-end rationality, since ethical encounters are not the rule but the exception, then racism too is not improbable but commonplace. Insofar as one is - according to the spontaneous dynamic existing, or conatus essendi, directed toward maintaining and sustaining the self - , one must be considered 'by nature' potentially racist, without of course being predestined or overdetermined by it. The I's racist tendencies are 'normal' as opposed to a psychological or pathological deviation limited to the few. Despite the 'normality' or commonplace occurrence of racism, it is nevertheless not a fated inevitability. Rather it is a permanent possibility woven into the dynamic of our being. By virtue of being, we are naturally inclined to reduce the face to the form in the interest of self-maintenance.

Levinas's conception of the absolute otherness of the Other person that poses ethical (as opposed to actual or concrete) resistance to assimilation by the self could perhaps be further elucidated by contrasting it to Tsenay Serequeberhan's exposition of the historical relation between the self (European culture) and the Other (Africa). ${ }^{24}$ Serequeberhan maintains that European culture established its identity by historically and thematically differentiating itself 
from "the Otherness of the Other" - exemplified by the barbarism of the Black African. What is at stake here is the constructed binary between the pureness of the White European that can only uphold this identity by radically opposing itself to its Other, which is conceived as nonassimilable. Here alterity is understood not as that which is fundamentally other and therefore not reducible to qualities, but fundamentally other precisely because of its contrasting qualities qualities that are so threatening in their opposition that the self cannot afford any encounter, recognition or assimilation without contamination. Here "the Otherness of the Other" is not the well-spring of ethical alterity, but the very legitimation of ethical violence. In 1967 Ezekiel Mphahlele resorted to this conception of otherness to explain the situation in the then Apartheid South Africa. Whites, he explained, maintained their identity by refusing to surrender to their African situatedness. Blacks, on the other hand, "have reconciled the Western and the African in them". Hence, "[t]he only cultural vitality there is, is to be seen among Africans; they have not been uplifted by a Western culture but rather they have reconciled the two in themselves". ${ }^{25}$

\section{Levinas and the Possibility of Dialogue with 'Strangers': Three Main Challenges}

Having established these basic markers of Levinas's thought, we can now turn to the critical assessment some of the stumbling blocks in the way of dialogue. Despite the ethical sensibility at the heart of Levinas's project, the spectres of his racism and Eurocentrism, premised on a very parochial conception of 'Europe', seems to thwart the way to any productive interchange. In what follows I would like to face these challenges head-on in a preliminary attempt to negotiate possible avenues around them. While it is beyond the scope of this essay to provide any definitive solutions, (which is perhaps beyond the scope and intent of any philosophical investigation), I offer a few suggestive proddings of the obstacles, which I address in terms of three main indictments or challenges: 


\subsection{First Challenge: the Distinction between Difference and Diversity}

The first challenge one encounters when attempting to engage Levinas's conceptualization of alterity from the perspective of the 'stranger', is the fact that it allows no distinction from, comparison to or derivation from identity. This has caused some commentators to be scathingly critical of Levinasian ethical responsibility. Hutchens, for example, maintains that "it consists in nothing but an empty caricature of a self responding without comprehension to an equally empty command that it could not know how to obey issuing from another person incoherently described"26

For Levinas, radical difference is abstract and in and of itself different. Since it is not relatively different, it simply cannot be compared to or distinguished from other others. Differences do not account for alterity; it is rather the fundamental otherness of alterity itself that gives rise to differences. As a result, Levinas would concede that alterity can become manifest in politically and empirically inspired differences, but these differences do not serve as markers for alterity as such, since it is not inherently tied to these differences. Levinas's work aims to provide a positive account of alterity in opposition to the negative accounts offered by Hegel and notions of identity based on negative or comparative difference. If Levinas precisely critiques the insistence upon distinguishing qualities as the root of other-reductive violence, the question is whether there is enough complementarity in their scope of reference for a productive interchange between ethical metaphysics and celebrations of or instances of insistence upon differences, characteristic of postcolonial African ethical discourses, for example?

Levinas has precisely been critiqued by Drabinski amongst others for his refusal to recognize diversity in difference. ${ }^{27}$ The most obvious counter-argument from a Levinasian perspective would be that the reintroduction of differentiation into difference would inevitably also reintroduce the problems of otherness overdetermined by their empirical, observable qualities, which precisely blind us to the face behind the form. The terror of totalizing identity cannot be combated by insisting on a counter-identity. Levinas's insistence upon the 'abstractness of the 
face' needs to be qualified in terms of his equally vehement contention that the face can only be accessed by way of the form. In other words, the absolute alterity of the other person manifests itself in the affectivity of the encounter between embodied selves. I can recognize you as you, beyond your complexion, gender, or ethnicity, because I am affected by virtue of your proximity to me. The proximity of another affects me by resonating with my infectedness by an other within myself that I cannot fathom. In other words, Levinas would insist upon an encounter with the embodied Other. The 'otherness' of the embodied Other might come in various forms, quintessentially the racial or ethnic other, but Levinas's point would be that these empirical differences do not encapsulate what truly singularizes us. Moreover, it is precisely this singularizing alterity that also makes for our fundamental human bond. We are all others to ourselves apart from being others to other persons. My whiteness does not make me more transparent to myself. In fact, my inner opaqueness is the 'difference' par excellence that singularizes me and therefore separates me from others, while rendering 'differences' moot. I would argue that if Levinas's disavowal of diversity in difference, on the one hand, and (postcolonial) celebrations of differences, on the other, are both animated by the conviction that self and Other are deserving of equal recognition, that the self is also another's Other, then there seems to be ample ground for productive and critical interchange precisely because of the difference in approaches.

\subsection{Second Challenge: Levinas's Racism and Eurocentrism}

The second major indictment that Levinas faces in the company of strangers is his racism and his emphatic Eurocentrism. As we have seen, he has been guilty of a number of flagrantly racist remarks and his work displays a patent Eurocentric bias. His Eurocentrism relies on a very parochial conception of Europe defined in terms of the Bible and the Greeks ${ }^{28}$, a conception that appears to discount the imperial violence constitutive of Europe. In my view, there are two possible ways to address these biases with a view to a possible dialogue: (1) first, by considering 
the context in which Levinas conceptualizes Europe in terms of the Bible and the Greeks; and (2) secondly, by considering his personal views (or racist remarks) in relation to his more systematic intellectual project.

Concerning the first, "Europe" or "Western culture", according to Levinas, is split between Greek and the Bible. "Greek" refers to "the manner in which the universality of the West is expressed ... rising above the local particularism(s)" ${ }^{29}$ For Levinas, "Greek is the language of totality, grounded in the correlations of subject and object, of self and world, actor and action, knower and known"30, which is the fundamental premise that gives rise to the other-reductive violence of ontology to which Levinas's ethical metaphysics is opposed. Levinas insists that the Bible teaches a different lesson, the lesson of ethics and responsibility. Levinas's primary goal in this essay ${ }^{31}$ in which he puts forward this parochial conception of Europe is to call attention to a crisis in European culture. The presiding Greek rationality, according to Levinas, is beset with the risk of draconian, organized oppression, dehumanization, and destruction as exemplified in the Gulag and Auschwitz. If "Europe" or "Western culture" is a contested identity - split between the contrary impulses of its combined Hellenic and Hebraic heritage -, then Levinas's Eurocentrism is premised on an European exceptionalism that attributes Europe's special position to its capacity for self-critique. For Levinas, this capacity for self-critique is made possible by its Hebraic heritage: the possibility of "an ontological inversion". ${ }^{32}$ The Bible, Levinas maintains, announces the possibility of interrupting the original perseverance of realities in their being, the very perseverance at the root of all evil - the evil of the Shoah as well as the evil of colonialism. The 'logic' on which Levinas's ethical metaphysics is premised is undeniably religiously inflected. This religious allegiance might serve to salvage his Eurocentrism for believers, but not so for those that have borne witness to the other-reductive violence of missionary origin. Levinas would counter that the violence of evangelical projects and institutions cannot undo "the little kindness" - "the goodness of one person toward another", "the rahamim [compassion, pity, mercy] of the Bible". 33 
In the second instance, if it is responsibility towards the Other that Levinas propounds manifest in but not limited to "compassion, pity and mercy" towards one's fellow human beings -, what then to make of his racist remarks? Can one legitimately separate the man, his personal political views, and ill-advised utterances from his more systematic body of thought? When it comes to ethical metaphysics (which is not an ethics or morality, to be sure), which insists upon racism/moral evil as an inherent possibility of the human that is constituted by its responsibility to the Other, can we maintain the death of the author, the separation of the text and the life, as Barthes and Foucault insisted, effectively privileging the systematic works over the interviews and personal views? In other words, do we not expect the character of the author preaching responsibility for the Other to lend credibility to his ideas, for are words not empty without deeds?

If one cannot separate the text and the life, perhaps Levinas's Eurocentrism, his racism and prejudice, provide credence to his ethical metaphysics rather than to discredit it. He is after all firmly steeped in the tradition of Western philosophy, even as he recognizes and critiques its constitutive violence to reduce all things other to the same. His insistence upon Europe as the wellspring of the human is contestable, since it privileges the same against all identities considered other. As argued above, Europe defined in terms of the Bible and Greek is itself thereby recognized as an inherently split self whose ethical impulse is often times overshadowed by its totalitarian tendencies. Would all other selves, by the same token, not also be spit selves, also prone to self-affirmation at the expense of the Other? Is this not the violence that Levinas alerts us to even if he cannot safeguard himself from such other-reductive inclinations?

What if, following Barthes, we subscribed to the idea that the author is dead, that he, his life, his intentions, do not have any definitive explanatory power? What if the life of the text, as Drabinski insists, ${ }^{34}$ and Levinas as well in response to a question about the status of commentary (in relation to the Talmud ${ }^{35}$ ), is to be found in commentary? It is in this context that Levinas insists that the question, 'Is my life righteous?' is trumped by the question, 'Is it righteous to be?'. 
Can we conclude from this that the fact that Levinas's own life was not entirely righteous does not discredit his insistence that being as such might not be righteous? Knowing nothing - by his own admission - about Buddhism, he insisted that for him the Bible is the model of excellence. ${ }^{36}$ He insists upon Europe ("alongside its numerous atrocities") and the Bible (in the name of love for the neighbour) knowing full well that neither Europe nor the Bible or Europe as the Bible and the Greeks represent pure identities, the Truth, or the uncontaminated moral good. Are both not examples par excellence of the kind of hybridity and mongrelization celebrated by Rushdie, even as they sometimes come cloaked in the guise of totalitarianism and the absolutism of the supposedly pure? Levinas frequently also identifies the West with Greek and opposes it both to Hebrew and to his Judaic inspired ethics of disruption, where both of the latter are understood as non-Western. There is evidence of a hesitation or vacillation between identifying Hebrew as an aspect of what is European and seeing Hebrew as marginalized otherness. His own hybrid identity as European Jew might account for this hesitation, but the fact is, neither Greek nor Hebrew and especially the combination of the two makes for a self-same Europe that neatly coincides with itself. Levinas's celebration of Europe, his Eurocentrism, should therefore also be read as a recognition of the constitutive otherness at the very heart of the self, that precisely accounts for the human aspect - the ability of Europe, alongside its numerous atrocities, to invent the idea of "de-Europeanization". "For the orientation of ethics in Levinas is not the condemnation of others, but the moment of self-questioning.

\subsection{Third Challenge: The A-political Nature of Levinas's Ethical Metaphysics}

The third indictment - and the last one that I will discuss within the limited scope of this essay is the fact that Levinas's philosophy is largely a-political. After reading Caygill's Levinas and the Political (2002) even those sympathizers reluctant to dismiss Levinas's philosophy as a-political have to concede that Levinas's views on political affairs have dealt a serious blow to the appeal and force of his insistence that we as humans bear an inherent responsibility for the Other. Only 
on occasion did Levinas show any interest in world affairs apart from his preoccupation with the Holocaust and the fate of the Jewish people. There remains a recalcitrant gap between ethics and politics in his thought even though he insists that ethics necessarily entails politics, that the ethical encounter between the self and the Other always also implicates other others. Yet, the singularizing asymmetric responsibility that cannot be evaded or delegated that issues from the face, that is, the pre-original, pre-reflective ethical responsibility, by necessity reintroduces thought, knowledge, and judgment (and with it, all the problems of ontology) when the abstracted face-to-face relationship assumes its rightful place in the world. In the world, the self has to compare the incomparable appeals of countless others competing for the scarce resources of the self.

Levinas attempts to address the issue of politics and justice by way of the Third. Levinas's ethical encounter - the face-to-face - is essentially a twosome, but in the real world the self constantly faces not one appeal, but countless others who are homeless, jobless, street-bound, kids left to their own devices, destitute, hungry, imploring, reminding one that your place in the sun is at the expense of others' well-being. Levinas's notion of the Third, whereby he attempts to represent the appeals of many others next to and in conjunction with the Other's address, as Drabinski rightly points out, "tends to function more as a phenomenology of how the political is signified in moral consciousness than an actual clarification or exploration of the meaning of political responsibility". ${ }^{38}$ In a discussion on the occasion of a conflict between Israel and Palestine, Levinas responds as follows to an interlocutor wanting to know if the Palestinian isn't the Israeli's "Other" above all:

"My definition of the other is completely different. The other is the neighbour, who is not necessarily kin, but who can be. And in that sense, if you're for the other, you're for the neighbour. But if your neighbour attacks another neighbour or treats him unjustly, what can you do? Then alterity takes on another character, in alterity we can find an 
enemy, or at least then we are faced with the problem of knowing who is wrong, who is just and who is unjust. There are people who are wrong". 39

From this response it seems as if in the case of Israel Levinas subordinates ethics to what is deemed just from a particular political perspective, sanctioned by the 'Sacred History'. His response seems to underwrite Sikka's indictment that his stress on the radical alterity of the other is not respectful of difference: "in fact Levinas leans towards a universalizing ethics that is not open to being informed by the dissimilar other, and that, moreover, privileges a particular culture in an insufficiently critical, and therefore, irresponsible, manner" ${ }^{40}$ In fact, for him, the alterity of transcendence is sharply differentiated from the alterity of strangers - those strangers in need of "translation", the "exotic, those relegated to the seemingly frivolous realm of "dance", those from a "lunar or Martian past", and all "those underdeveloped Afro-Asiatic masses who are strangers to the Sacred History that forms the heart of the Judaic Christian world". ${ }^{41}$ In alterity, Levinas insists, "we can find an enemy" and it seems to be especially the "strangers" that bear this threatening potential.

To navigate the moment of transition from the ethical to the political, Levinas invokes the Judeo-Christian trope of the messianic, which functions to signal a sort of pure futurity. In the here and now, we are faced with the reality of our ontological inclination towards evil, with the failure of institutions such as the state to institute and maintain justice. In Totality and Infinity, Levinas insists that war, other-reductive evil, and injustice can only be overcome if time itself is reconceptualized in terms of the messianic "infinite time of triumph" that signals perpetual peace $^{42}$ : "Messianic triumph is the pure triumph; it is secured against the revenge of evil" ${ }^{43}$, that is, the victory of peace over war. Messianic time, time as the Other and the future, as Levinas explains in Time and the Other ${ }^{44}$, epitomizes the transition from ontology to ethics or from philosophy to the religious. ${ }^{45}$ As the preceding discussion testifies and Drabinski explicitly asserts, "such a moment, while critical and diagnostic of the present in its illumination of injustice, does not lend itself to prescribing just political action" ${ }^{46}$ in the here and now, that is, the 
transition from the otherwise than being to the plane of being, which raises the question of action, mobilization and resistance.

Also, at a more fundamental theoretical level, Levinas's respective conceptualizations of ethics and politics seem inherently incompatible, even opposed: the ethical subject is stripped of her ego, denucleated, imploding under the weight of the world, radically passive; the political subject, on the other hand, is called back from this place of an-archic preconscious responsibility that incapacitates, to compare the incomparable, to judge and to act - knowing full well that every and any action will invariably deny other others' appeals.

Following Derrida's Adieu, Simon Critchley offers one possible workable negotiation between ethics and politics in Levinas's thought ${ }^{47}$ : Politics, Critchley maintains, demands inventing a new normative guideline for every situation, a norm premised on the Other's ethical injunction lodged in me. This injunction is nonfoundational yet nonarbitrary even though each decision is necessarily different in response to the singular demand made on me by each other Other in his or her specific context. "Every time I decide I have to invent a new rule, a new norm, which must be absolutely singular in relation to both the Other's infinite demand made on me and the finite context within which this demand arises". He further explains that "each political decision is made experiencially ex nibilo, as it were, and is not deduced or read off procedurally from a pregiven moral content, and yet it is not arbitrary: a rule shapes the taking of that decision". ${ }^{48}$ This attempt to save Levinas's ethical metaphysics from some of its inherent contradictory impulses would only be convincing - convincing also to "strangers" - if it is supplemented by Derrida's qualification. Derrida accepts Levinas's formal notion of the ethical relation to the Other, that is, the latter's insistence upon the messianic, while refusing the specific political content that Levinas's ethical thought seems to entail - his Zionism, French republicanism, and Eurocentrism, which necessarily includes the violence of imperial expansion and usurpation. ${ }^{49}$ 


\section{Some Inconclusive Concluding Thoughts}

Needless to say, within the limited scope of this programmatic essay one cannot flesh out these issues in all their complexity. If a meaningful and instructive dialogue between Levinas and those considered "strange" from his perspective is to be possible, one would have to avoid the "anodyne pieties" that a thinker like Levinas can offer. The most dangerous and the least instructive readings of Levinas - the kind of readings that unfortunately abound especially in non-philosophical disciplinary contexts - amount to a kind of defensive sermonizing. We have to acknowledge that even Levinas - like most of his potential interlocutors - is a situated thinker, riddled with explicit and unconscious biases deriving from his particular personal history and intellectual heritage. Acknowledging these prejudices are not enough; the task before us is the intellectual labour needed to navigate through them - for no thinker is truly and always "beyond being". The required intellectual labour consists in finding the gaps where a meaningful encounter would be possible. Levinas's critique of ontology might be such gap. Eaglestone ${ }^{50}$ proposes that "Levinas's critique of ontology is a way of exploring in detail the philosophical discourse that underlies Western thought precisely in terms of its colonial and all-consuming power". ${ }^{51}$ He suggests that it is not in the first instance the ethical call that seems to speak out against colonialism, but the way in which Levinas construes the history of Western philosophy as reduction of the other to the same, which serves as necessary condition for the realization that we need to "decolonize the mind". Decolonizing the mind would by necessity mean challenging the opposition between the alterity of transcendence and the alterity of strangers - an opposition that Levinas's thinking seems to imply. I suspect that the interstices of the ethical - the moments of radical passivity in which the self's conatus is momentarily suspended - opens up a space in which this opposition might effectively be neutralized enabling a meaningful encounter between Levinas and those interlocutors otherwise considered "strange" and in need of "translation". 


\section{List of References}

P. Atterton and M. Calarco (eds.) (2010) Radicalizing Levinas (Albany: Suny Press).

K. A. Appiah (1992) In My Father's House: Africa in the Philosophy of Culture (Oxford: Oxford University Press).

R. H. Bell (2002) Understanding African Philosopby: A Cross-cultural Approach to Classical and Contemporary Issues (New York: Routledge).

R. Bernasconi (1990) 'One-Way Traffic: The Ontology of Decolonization and its Ethics', in G. Johnson and M. Smith (Ed.)(1990) Ontology and Alterity in Merleau-Ponty (Evanston IL: Northwestern University Press), pp. 67-80.

R. Bernasconi (1992) 'Who Is My Neighbour? Who Is the Other? Questioning the "Generosity of Western Thought"' in Ethics and Responsibility in the Phenomenological Tradition (Pittsburgh, PA: Simon Silverman Phenomenology Center, Duquesne University), pp. 1-31.

R. Burggraeve (1999) 'Violence and the Vulnerable Face of the Other: The Vision of Emmanuel Levinas on Moral Evil and Our Responsibility', Journal of Social Philosophy, 30(1), 29-45.

R. Burggraeve, R. (2009) 'Affected by the Face of the Other. The Levinasian Movement from the Exteriority to the Interiority of the Infinite', in Dialegesthai. Rivista telematica di filosofia, 11. Available online: http://mondodomani.org/dialegesthai/ ISSN 1128-5478 Accessed 30 November 2015.

H. Caygill (2002) Levinas and the Political (London: Routledge).

S. Critchley (2010) 'Five Problems in Levinas's View of Politics and the Sketch of a Solution to Them' in P. Atterton and M. Calarco (eds.) Radicalizing Levinas (Albany: Suny Press), pp. 41-53. J. E. Drabinski (2011) Levinas and the Postcolonial. Race, Nation, Other (Edinburgh: Edinburgh University Press).

R. Eaglestone (2010) 'Postcolonial Thought and Levinas's Double Vision' in P. Atterton and M. Calarco (eds.) Radicalizing Levinas (Albany: Suny Press), pp. 57-68.

S. Hand (Ed.) (1989) The Levinas Reader (Oxford: Blackwell). 
A. B. Hofmeyr (Ed.) (2009) Radical Passivity. Rethinking Ethical Agency in Levinas. Dordrecht, NL: Springer. Book Series: Library of Ethics and Applied Philosophy. ISBN: 978-1-4020-9346-3

A. B. Hofmeyr (2009) 'Radical Passivity: Ethical Problem or Solution?', in Hofmeyr, A. B. (Ed.) 2009: 25-49.

A. B. Hofmeyr (2010) 'From Activity to Radical Passivity: Rethinking Ethical Agency in Levinas', in Monokl 8-9: 97-117.

B. C. Hutchens (2004) Levinas. A Guide for the Perplexed (New York: Continuum).

E. Levinas (1963) 'Le débat russo-chinois et la dialectique' in E. Levinas Diffcile liberté: essais sur le judaïsme (Paris: Albin Michel). This article is not included in the English version of Difficult Freedom.

E. Levinas (1964) 'Meaning and sense' in A. Peperzak, S. Critchley and R. Bernasconi (eds.) (1996) Emmanuel Levinas. Basic Philosophical Writings (Bloomington and Indianapolis: Indiana University Press), pp. 33-64.

E. Levinas (1979) Totality and Infinity. An Essay on Exteriority, trans. Alphonso Lingis. (The Hague: Martinus Nijhoff). In French: (1961) Totalité et infini (The Hague: Martinus Nijhoff).

E. Levinas (1987) Time and the Other, trans. R. Cohen. (Pittsburgh: Duquesne University Press). In French: (1948) Le temps et l' autre (Grenoble \& Paris: B. Arthaud).

E. Levinas, E (1985) Ethics and Infinity. Conversations with Philippe Nemo, trans. Richard A. Cohen. (Pittsburgh: Duquesne University Press). In French: (1982) Éthique et infini. Dialogues avec Philippe Nemo. Librairie Arthème Fayard et Radio-France, L'espace intérieur 26.

E. Levinas (1988) 'La vocation de l'autre' in E. Hirsch (ed.) Racismes. L'autre et son visage (Paris: Cerf), pp. 89-102.

E. Levinas (1990) 'Jewish Thought Today', in Difficult Freedom: Essays on Judaism. (London: Athlone Press), pp. 159-166.

E. Levinas (1991) Othervise than Being or Beyond Essence, trans. Alphonso Lingis. (Dordrecht: Kluwer Academic Publishers). In French: (1974) Autrement qu'être ou au-delà de l'essence (The 
Hague: Martinus Nijhoff) [the original French page references follow that of the English translation].

E. Levinas (1994) Les imprevus de l'histoire. (Fata Morgana).

E. Levinas (1996) Nouvelles lectures talmudiques (Paris: Minuit).

E. Levinas (2007) [1994] In the Time of the Nations, trans. Michael B. Smith. (London: Continuum).

L. Ma (2008) 'All the Rest Must Be Translated: Levinas's Notion of Sense' in Journal of Chinese

Philosophy, pp. 599-612.

M. Mamdani (2001) 'Beyond Settler and Native as Political Identities: Overcoming the Political Legacy of Colonialism', Society for Comparative Study of Society and History 0010-4175, 651-664.

A. McGettigan (2006) 'The Philosopher's Fear of Alterity. Levinas, Europe and Humanities 'Without Sacred History', in Radical Philosopby 140: 15-25.

M. L. Morgan (2011) The Cambridge Introduction to Emmanuel Levinas (Cambridge: Cambridge University Press).

R. Mortley (1991) French Philosophers in Conversation. (London: Routledge).

E. Mphahlele (1967) 'Remarks on Negritude' in African Writing Today (Harmondsworth: Penguin).

J. Robbins (ed.) (2001) Is it Righteous To Be? Interviews with Emmanuel Levinas (Stanford, California: Stanford University Press).

T. Serequeberhan (1994) The Hermeneutics of African Philosophy (New York: Routledge).

S. Sikka (1999) 'How Not to Read the Other? "All the Rest Can Be Translated"', in Philosophy Today 43(2): 195-206. 


\section{Endnotes}

${ }^{1}$ E. Levinas (1964) 'Meaning and sense' in A. Peperzak, S. Critchley and R. Bernasconi (eds.) (1996) Emmanuel Levinas. Basic Philosophical Writings (Bloomington and Indianapolis: Indiana University Press), pp. 33-64; L. Ma (2008) 'All the Rest Must Be Translated: Levinas's Notion of Sense' in Journal of Chinese Philosophy pp. 599-612.

${ }^{2}$ Cf. Levinas (1994) Les imprevus de l'bistoire. Fata Morgana.

${ }^{3}$ E. Levinas (1994) Les imprevus de l'histoire, p. 171 cited in H. Caygill (2002) Levinas and the Political (London: Routledge), p. 184.

${ }^{4}$ Ibid.

${ }^{5}$ Levinas, Les imprevus de l'histoire, p. 172.

${ }^{6}$ Caygill, Levinas and the Political, p. 184.

${ }^{7}$ (E. Levinas (1990) 'Jewish Thought Today' in Difficult Freedom: Essays in Judaism (London: Athlone Press), pp. 159-166.

${ }^{8}$ Ibid., p. 160.

${ }^{9}$ Cf. Ma, 'All the Rest Must Be Translated', p. 605.

${ }^{10}$ R. Mortley (1991) French Philosophers in Conversation. (London: Routledge), p. 18.

${ }^{11}$ S. Critchley (2010) 'Five Problems in Levinas's View of Politics and the Sketch of a Solution to Them' in P. Atterton and M. Calarco (eds.) Radicalizing Levinas (Albany: Suny Press), p. 44.

${ }^{12}$ E. Levinas (2007) In the Time of the Nations, trans. Michael B. Smith (London: Continuum), pp. $119-121$.

${ }^{13}$ Cf. R. Bernasconi (1990) 'One-Way Traffic: The Ontology of Decolonization and its Ethics', in G. Johnson and M. Smith (Ed.)(1990) Ontology and Alterity in Merleau-Ponty (Evanston IL: Northwestern University Press), pp. 67-80; idem. (1992) 'Who Is My Neighbour? Who Is the Other? Questioning the "Generosity of Western Thought" in Ethics and Responsibility in the 
Phenomenological Tradition (Pittsburgh, PA: Simon Silverman Phenomenology Center, Duquesne University), pp. 1-31;

${ }^{14}$ H. Caygill (2002) Levinas and the Political (London: Routledge), p. 185.

${ }^{15}$ E. Levinas (1991) Otherwise Than Being or Beyond Essence, trans. Alphonso Lingis. (Dordrecht: Kluwer Academic Publishers). In French: (1974) Autrement qu'être ou au-delà de l'essence (The Hague: Martinus Nijhoff), pp. 4-5/4-5.

${ }^{16}$ E. Levinas, E (1985) Ethics and Infinity. Conversations with Philippe Nemo, trans. Richard A. Cohen. (Pittsburgh: Duquesne University Press). In French: (1982) Éthique et infini. Dialogues avec Philippe Nemo. Librairie Arthème Fayard et Radio-France, L’espace intérieur 26, pp. 90-91.

${ }^{17}$ Reference to Malcolm X's distinction in Mamdani, 'Beyond Settler and Native', p. 657.

${ }^{18}$ E. Levinas (1996) Nouvelles lectures talmudiques (Paris: Minuit), pp. 22-23.

${ }^{19}$ For a more detailed account of this movement, see R. Burggraeve, R. (2009) 'Affected by the Face of the Other. The Levinasian Movement from the Exteriority to the Interiority of the Infinite', in Dialegesthai. Rivista telematica di filosofia, 11. Available online: http://mondodomani.org/dialegesthai/ ISSN 1128-5478 Accessed 30 November 2015; A. B. Hofmeyr (2009) 'Radical Passivity: Ethical Problem or Solution?', in Hofmeyr, A. B. (Ed.) 2009: 25-49; A. B. Hofmeyr (2010) 'From Activity to Radical Passivity: Rethinking Ethical Agency in Levinas', in Monokl 8-9: 97-117.

${ }^{20}$ Levinas, Otherwise Than Being, p. 141/179.

${ }^{21}$ In this regard, see R. Burggraeve (1999) 'Violence and the Vulnerable Face of the Other: The Vision of Emmanuel Levinas on Moral Evil and Our Responsibility', Journal of Social Philosophy, 30(1), pp. 39-42.

${ }^{22}$ E. Levinas (1988) 'La vocation de l'autre' in E. Hirsch (ed.) Racismes. L'autre et son visage (Paris: Cerf), p. 92.

${ }^{23}$ Levinas, Meaning and Sense, p. 53. 
${ }^{24}$ T. Serequeberhan (1994) The Hermeneutics of African Philosophy (New York: Routledge), p. 128.

${ }^{25}$ E. Mphahlele (1967) 'Remarks on Negritude' in African Writing Today (Harmondsworth: Penguin), p. 248.

${ }^{26}$ B. C. Hutchens (2004) Levinas. A Guide for the Perplexed (New York: Continuum), p. 54.

${ }^{27}$ J. E. Drabinski (2011) Levinas and the Postcolonial. Race, Nation, Other (Edinburgh: Edinburgh University Press).

${ }^{28}$ Levinas, In the Time of the Nations, pp. 119-121.

${ }^{29}$ Levinas, In the Time of the Nations, pp. 120-121.

${ }^{30}$ M. L. Morgan (2011) The Cambridge Introduction to Emmanuel Levinas (Cambridge: Cambridge University Press), p. 186.

${ }^{31}$ First published in Cosmopolitiques 4 (February 1986).

${ }^{32}$ Levinas, In the Time of the Nations, p. 119.

${ }^{33}$ Levinas, In the Time of the Nations, p. 121.

${ }^{34}$ Drabinski, Levinas and the Postcolonial, p. xi.

${ }^{35}$ J. Robbins (ed.) (2001) Is it Righteous To Be? Interviews with Emmanuel Levinas (Stanford, California: Stanford University Press), p. 163.

${ }^{36}$ Levinas, Is it Righteous to Be?, p. 164.

${ }^{37}$ Levinas, Is it Righteous to Be?, p. 164.

${ }^{38}$ Drabinsky, Levinas and the Postcolonial, p. 167.

${ }^{39}$ S. Hand (Ed.) (1989) The Levinas Reader (Oxford: Blackwell), p. 294.

${ }^{40}$ S. Sikka (1999) 'How Not to Read the Other? "All the Rest Can Be Translated”, in Philosophy Today 43(2): 195.

${ }^{41}$ Levinas, "Jewish Thought Today", p. 160.

${ }^{42}$ Levinas, Totality and Infinity, pp. 281-285/257-261.

${ }^{43}$ Levinas, Totality and Infinity, p. 285/261. 
${ }^{44}$ E. Levinas (1987) Time and the Other, trans. R. Cohen. (Pittsburgh: Duquesne University Press). In French: (1948) Le temps et l' autre (Grenoble \& Paris: B. Arthaud).

${ }^{45}$ In this regard, see H. Caygill (2002) Levinas and the Political (London: Routledge), pp. 97-98.

${ }^{46}$ Drabinsky, Levinas and the Postcolonial, p. 168.

${ }^{47}$ S. Critchley (2010) 'Five Problems in Levinas's View of Politics and the Sketch of a Solution to Them' in P. Atterton and M. Calarco (eds.) Radicalizing Levinas (Albany: Suny Press), pp. 41-53.

${ }^{48}$ Critchley, 'Five Problems', pp. 48-49.

${ }^{49}$ Critchley, 'Five Problems', p. 49.

${ }^{50}$ R. Eaglestone (2010) 'Postcolonial Thought and Levinas's Double Vision' in P. Atterton and M. Calarco (eds.) Radicalizing Levinas (Albany: Suny Press), pp. 57-68.

${ }^{51}$ Eaglestone, 'Postcolonial Thought', p. 64. 